Arq. Bras. Med. Vet. Zootec., v.69, n.2, p.310-316, 2017

\title{
Influence of orchiectomy of seven month old bulls on bronchoalveolar immune function
}

\author{
[Influência da orquiectomia na função imune broncoalveolar de garrotes de sete meses de idade] \\ H.G. Bertagnon ${ }^{1,2}$, C.F. Batista ${ }^{1}$, B.P. dos Santos $^{1}$, M.G.B. Lima ${ }^{1}$, \\ J.B. Bellinazzi ${ }^{1}$, A.M.M.P. Della Libera ${ }^{1}$ \\ ${ }^{1}$ Faculdade de Medicina Veterinária - Universidade de São Paulo - São Paulo, SP \\ ${ }^{2}$ Universidade Estadual do Centro Oeste - Guarapuava, PR
}

\begin{abstract}
The present study evaluated the impact that orchiectomy, a routine but painful intervention in bovine husbandry, can cause on pulmonary immunity. To identify whether orchiectomy can impair lung defense, analyses of serum cortisol concentration and of alveolar macrophage and their function (phagocytosis and respiratory burst) were evaluated. Sixteen Holstein bulls ( 7 mo old, $250 \pm 50 \mathrm{~kg}$ of body weight BW) were divided in two homogeneous groups - the castrated group and the sham group - and the sample were collected on Days -7, 1 and 7 relative to the day of the procedure. Serum cortisol concentration statistically increased on

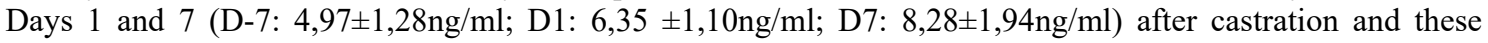
variables seem to impact the alveolar macrophage percentage on D1 (D-7: 76,86 $\pm 3,44 \%$; D1: 60,92 $\pm 2,44 \%$; D7: $74,17 \pm 2,56 \%)$ and their respective function of phagocytosis $(\mathrm{P})$ and the oxidative burst (OB) on Days 1 and 7 for the castrated group (P D-7: $56,25 \pm 15,63$ arbitrary values; D1: $54,75 \pm 14,07$ arbitrary values; D7: $31,77 \pm 8,44$ arbitrary values; and OB D-7: $222,34 \pm 39,52$ arbitrary values; D1: $135,25 \pm 37,68$ arbitrary values; D7: $117,73 \pm 18,17$ arbitrary values). These results indicate that surgical castration affected lung defense until seven days after the practice, so the pulmonary cell function was impaired for a period higher than that reported in the literature.
\end{abstract}

Keywords: cattle, cortisol, innate immunity, phagocytosis

\section{RESUMO}

O presente estudo avaliou o impacto que a orquiectomia, uma intervenção dolorosa comumente realizada durante a criação de bovinos, pode causar na imunidade pulmonar. Para tanto, foram realizadas dosagens de cortisol sérico, bem como a análise de macrófagos alveolares e suas funções (fagocitose e metabolismo oxidativo) de 16 bovinos da raça Holandesa preto e branco (sete meses de idade, 250 $50 \mathrm{~kg}$ de peso vivo). Esses animais foram divididos aleatoriamente em dois grupos homogêneos - grupo castrado e grupo controle - e foram avaliados nos dias -7, 1 e 7, relativos ao dia do procedimento cirúrgico, que foi realizado no dia 0 . A concentração de cortisol sérico aumentou estatisticamente nos dias 1 e 7 em relação ao grupo controle (D-7:

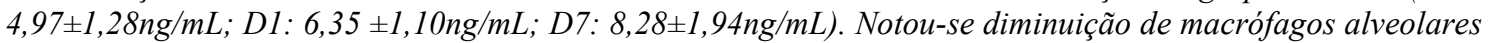

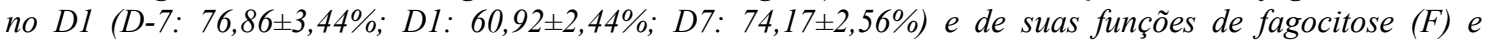

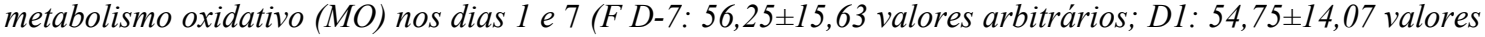

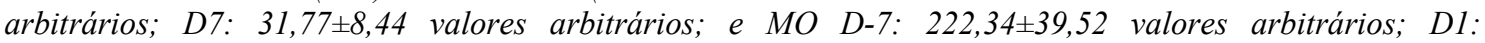

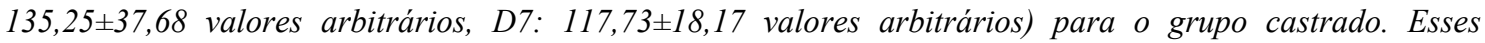
resultados demonstram que a orquiectomia afeta as defesas pulmonares por até sete dias após a prática, periodo superior ao relatado pela literatura.

Palavras-chave: bovino, cortisol, imunidade inata, fagocitose

\section{INTRODUCTION}

The castration of male cattle is routine practice in many countries, and although widely studied, no satisfactory protocol has been developed regarding the appropriate age or the best castration technique for reducing distress to the patient (Anderson, 2004; Stafford et al., 2002). Although some authors consider castration surgery with anesthesia and ketoprofen as the

Recebido em 15 de setembro de 2016

Aceito em 30 de setembro de 2016

E-mail: hbertagnon@unicentro.br 
standard technique for reduced pain and faster cicatrization (Stafford, 2002; Pang et al, 2009; Coetzee et al, 2010), there is currently no consensus (Becker et al, 2012)

Bovine Respiratory Diseases (BRD) cause major economic losses in husbandry (Pinchak et al, 2004), and these diseases are common following castration (Snowder et al, 2008). Numerous studies on the effects of castration on acute stress, cortisol production, decrease in performance and the blood immune response have been conducted (Ting et al., 2003; Ballou et al., 2013). However, to our knowledge, we only found one study about the evaluation of this type of stress on respiratory immune cells, conducted by our researchers. This study showed that orchiectomy alters the blood and respiratory tract leucocytes, but whether or not stress effect can impair alveolar macrophage function wasn't evaluated (Bellinazzi et al, 2013).

Previous studies have been conducted to identify increases in morbidity from BRD such as pneumonia (Pinchak et al, 2004) or increased colony forming units in lung samples (Mac Vean et al, 1986), associations that could be influenced by various other factors such as environmental conditions or poor management of than immunological response exclusive (Taylor et al., 2010).

Stressful situations such as shipping and meteorological conditions have been demonstrated to impair respiratory tract defenses, by altering the location and the efficiency of alveolar macrophage phagocytosis and neutrophil respiratory bursts (Ishizaki et al, 2005; Bertagnon et al, 2011). We hypothesed that orchiectomy also can induce the occurrence of respiratory disease for the same reasons.

As the initial defense of the respiratory tract is initiated by resident cells that recruit other blood leukocytes to maintain the health of the respiratory tract (Ackermann et al, 2010), the present hypothesis was that orchiectomy, a routine painful challenge even when followed by an analgesic protocol, can alter bronchoalveolar cell function and decrease lung defense. Thus, the aim of this study was to verify the influence of orchiectomy on bull's respiratory tract immunity by analyzing alveolar macrophages function (oxidative burst and phagocytosis) and on serum cortisol concentrations.

\section{MATERIALS AND METHODS}

The whole study procedure was approved by the Ethics Committee of the Faculty of Veterinary Medicine and Animal Science of University of São Paulo (2395/2011).

The sixteen Holstein calves used in this study had been previously habituated to intensive handling since they were five months old. They were completely acclimated to the new environment for 60 days, showing a calm temperament at all points in the experiment. They were deemed healthy based on history and physical examination, and they do not receive any preventive treatments such as vaccinations or anti-parasitic drugs during the acclimation or experimental period. Calves were housed in naturally ventilated pens ( 4 x $4 \mathrm{~m}$ ), with 2 or 3 animals per pen. Each pen had sawdust bedding, which was replaced once daily. The diet consisted of a balanced, mixed ration containing hay and commercial calf pellets. Calves had ad libitum access to feed and water. Fresh feed was provided, and refused feed was removed twice daily.

After an acclimation period, surgical castration was performed on eight bulls ( 7 months old, $250 \pm 50 \mathrm{~kg}$ of $\mathrm{BW})$. As part of the castration procedure, gentle manual restraint of the bulls was carried out with $0.02 \mathrm{mg} / \mathrm{kg}$ - IM $0.2 \%$ xylazine chloride (Rompum, Bayer Rio de Janeiro, Brazil). Local anesthesia was provided using 2\% lidocaine hydrochloride (lidocaine, Hipolabor, São Paulo, Brazil) administered 20 min before treatment, followed by $2 \mathrm{~mL}$ of lidocaine injected into each spermatic funicle. A further $3 \mathrm{~mL}$ of lidocaine was injected s.c. along each subsequent incision line on the scrotum. After that, two incisions were made to the caudoventral scrotum with a scalpel, the testicles were expressed and hemostasis of the spermatic cord vessels was achieved by first crushing the spermatic cord and then ligating it with a nontransfixing absorbable suture material. Then, an incision was made to remove the spermatic cords and their respective testes $2 \mathrm{~cm}$ beyond the ligation (Anderson, 2004). The nonsteroidal antiinflammatory ketoprofen (Ketojet, Agener União, São Paulo, Brazil) was provided by 
infusion of $3 \mathrm{mg} / \mathrm{kg}$-IV $\mathrm{BW}$, which was administered $20 \mathrm{~min}$ before orchiectomy and 24 $\mathrm{h}$ after the procedure.

A sham group of eight Holstein bulls (7 months old, $250 \pm 50 \mathrm{~kg}$ of BW) were sham-castrated by washing and handling the scrotum as if to castrate, and xylazine and ketoprofen were administered as with the castrated group. After castration or sham-castration, the bulls were walked back to their pens, where fresh feed was available.

Then, both groups were subjected to a serial collection of bronchoalveolar lavage (BAL) and serum cortisol at D -7, 1 and $7 \mathrm{~d}$ relative to day of the orchiectomy, always at same hour of the day to avoid circadian variations that could interfere with cortisol serum measurements.

BAL samples were collected by bronchoscopy with a flexible video endoscope (EC-250LP5, Fujinon $\left.^{\circledR} 1,690 \mathrm{~mm} \quad \mathrm{X} \quad \varnothing 11 \mathrm{~mm}\right)$ inserted nasopharyngeally up to the bronchus; $80 \mathrm{~mL}$ of $0.9 \%$ sterile saline solution was injected through the equipment's working channel and then aspirated with a surgical vacuum cleaner (Batista et al, 2012), thus achieving a recovery of approximately $50 \mathrm{~mL}$ of BAL.

To maintain cell viability, all samples were kept in a cool box until being processed within 3 hours of collection. The samples were submitted to two lavages with PBS (phosphate-buffered saline, after) and centrifugation (at $1000 \mathrm{xg}$ at $4^{\circ} \mathrm{C}$ for $15 \mathrm{~min}$ and $400 \mathrm{xg}$ at $4^{\circ} \mathrm{C}$ for $10 \mathrm{~min}$ ). The cell pellet was resuspended in $1 \mathrm{~mL}$ of cell culture medium (RPMI 1640) supplemented with $10 \%$ fetal bovine serum (FBS). The cell viability were assessed by a trypan blue. All sample showed a cell viability bigger than $90 \%$. Then, the cell suspension was adjusted to $2 \times 10^{6}$ viable cells $/ \mathrm{mL}$ for the immune evaluations.

The function of alveolar macrophages was evaluated by an analysis of the oxidative burst and phagocytic activity with flow cytometry following Batista et al. (2012). The alveolar macrophage was identified by selecting for auto fluorescence following Soethout et al. (2004). The oxidative burst was evaluated by measuring the hydrogen peroxide $\left(\mathrm{H}_{2} \mathrm{O}_{2}\right)$ activity, as indicated by intracellular oxidation of 2,7dichlorofluorescein diacetate (DCFH), based on a protocol reported by Batista et al. (2012). Briefly, the bronchoalveolar cells $\left(2 \times 10^{6}\right.$ cells $/ \mathrm{mL}$ ) were incubated with $200 \mu \mathrm{L}$ of DCFH in $1.2 \%$ phosphate-buffered saline (PBS) solution with $1.2 \%$ stimulus (incubation with Staphylococcus aureus conjugated with propidium iodide (Sa-PI) at $25 \times 10^{6}$ bacteria / $\mathrm{mL})$ at $37{ }^{\circ} \mathrm{C}$ for 30 minutes. The phagocytic activity was assessed by measuring the Sa-PI internalized by the leukocytes. The two assays were analyzed using a FACSCalibur ${ }^{\mathrm{TM}}$ flow cytometer and CellQuest ${ }^{\circledR}$ software (Becton Dickinson Immunocytometry Systems ${ }^{\mathrm{TM}}$ ). The flow cytometer calibration and analysis were based on 30,000 events collected for each tube, and the results were evaluated using the FlowJo ${ }^{\circledR}$ software (version 7.6.5 for Windows; Tree Star, USA). The results of alveolar macrophage and their functions of the phagocytic activity and of the oxidative burst are presented as a percentage (\%) and as the geometric mean fluorescence intensity (GMFI).

Blood samples (approximately $8 \mathrm{~mL}$, without anticoagulant) were collected using catheters for subsequent cortisol assays on Day -7 (seven days before the procedure) and on Days 1 and 7 relative to the time of treatment for each bull. Plasma samples were isolated from blood samples after centrifugation at $1600 \mathrm{xg}$ at room temperature for $15 \mathrm{~min}$ and stored at $-80^{\circ} \mathrm{C}$ until analyzed. Serum cortisol concentrations were determined in duplicate using a commercially

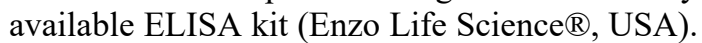
The intra- and intervariability of the assay were $6.6 \%$ and $7.8 \%$, respectively.

Analyses were conducted using GraphPad InStat statistical software (GraphPad Software, La Jolla, USA). Significance was declared when $P \leq$ 0.05 . Results with $P$ values between 0.06 and 0.1 were considered to approach significance and are reported as tendencies. The data were submitted to a normality test (Kolmogorov and Smirnov). Normal variables with repeated measures are reported as least squares and standard error of the means (SEM) and were analyzed using repeated measures ANOVA. When an effect was significant, Tukey's test was used to assess the significance among the time points. For all data, an unpaired $t$-test was used to detect treatment differences 


\section{RESULTS}

There were no significant differences in the serum cortisol concentrations at any given time point for either group. However, the serum cortisol concentration was greater on Day 1 and 7 for the castrated than the sham group $(P=$ 0.007 and 0.02 , respectively) (Table 1).

Table 1. Mean serum cortisol concentration (least square means \pm SEM; ng $/ \mathrm{mL}$ ) of castrated or sham bulls before (Day -7) and after orchiectomy (Days 1 and 7)

\begin{tabular}{ccccc} 
Cortisol $(\mathrm{ng} / \mathrm{mL})$ & \multicolumn{4}{c}{ Time relative to orchiectomy, day } \\
& $\mathrm{D}-7$ & $\mathrm{D} \mathrm{1}$ & $\mathrm{D} 7$ & $P$ \\
\hline Castrated & $4.97 \mathrm{aA}$ & $6.35 \mathrm{aA}$ & $8.28 \mathrm{aA}$ & \\
& \pm 1.28 & \pm 1.10 & \pm 1.94 & \\
& $4.21 \mathrm{aA}$ & $2.27 \mathrm{aB}$ & $2.25 \mathrm{aB}$ & 0.28 \\
Sham & \pm 1.63 & \pm 0.16 & \pm 0.33 & \\
$P$ & 0.72 & 0.007 & 0.02 & \\
\hline
\end{tabular}

Uppercase letters (A,B) indicate significant differences between groups, and lowercase letters (a) indicate no significant differences between the time for each group. $(\mathrm{P} \leq 0.05)$.

In general, the procedure negatively influenced bronchoalveolar cell function (Tab. 2). There was a decrease on the percent of alveolar macrophages (time interaction $P=0,001$ and group interaction $P=0,03$ ) and on the percent of alveolar macrophages that were phagocytizing and phagobursting on Day 1 for the castrated group $(P=0.02$ and $P=0.03$ time interaction and $P=0.0003$ and $P=0.09$ group interaction).
There was a decrease on the percent of alveolar macrophages that were phagocytizing on Day 7 (group interaction $P=0 \quad .05$ and 0.08 time interaction) for the castrated group and a progressive decreased on the GMFI of phagobursting on Day 1 and 7 (Time interaction $P=0.05$ on Day1 $\mathrm{P}=0.01$ on Day 7 and group interaction $\mathrm{P}=0.1$ on Day1 and 0.05 on Day 7 for the castrated group).

Table 2. Alveolar macrophage (AM) and their function: percentage and geometric mean fluorescence intensity (GMFI) of AM underwent phagocytosis and oxidative burst of castrated and sham bulls before (Day -7) and after orchiectomy (Days 1 and 7) (least square means \pm SEM)

\begin{tabular}{|c|c|c|c|c|c|c|c|}
\hline & & ime relativ & to orchiec & omy, day & & & \\
\hline Alveolar macron & s and their & & -7 & $\mathrm{D}$ & 1 & & 7 \\
\hline fu & & Cast & Sham & Cast & Sham & Cast & Sham \\
\hline $\begin{array}{l}\text { Alveolar } \\
\text { macrophages }\end{array}$ & $(\%)$ & $\begin{array}{c}76.86 \mathrm{aA} \\
( \pm 3.44)\end{array}$ & $\begin{array}{c}78.40 \mathrm{aA} \\
( \pm 1.38)\end{array}$ & $\begin{array}{c}60.92 \mathrm{bB} \\
( \pm 2.44)\end{array}$ & $\begin{array}{l}75.05 \mathrm{aA} \\
( \pm 3.10)\end{array}$ & $\begin{array}{l}74.17 \mathrm{aA} \\
( \pm 2.56)\end{array}$ & $\begin{array}{c}75.30 \mathrm{aA} \\
( \pm 1.85)\end{array}$ \\
\hline Phagocytosis & $(\%)$ & $\begin{array}{l}59.61 \mathrm{aA} \\
( \pm 2,63)\end{array}$ & $\begin{array}{l}68.66 \mathrm{aA} \\
( \pm 5.70)\end{array}$ & $\begin{array}{l}46.84 \mathrm{bB} \\
( \pm 1.87)\end{array}$ & $\begin{array}{c}70.36 \mathrm{aA} \\
( \pm 4.50)\end{array}$ & $\begin{array}{l}51.17 \mathrm{aB} \\
( \pm 3.86)\end{array}$ & $\begin{array}{c}60.4 \mathrm{aA} \\
( \pm 3.23)\end{array}$ \\
\hline & $\begin{array}{c}\text { GMFI } \\
\text { (arbitrary } \\
\text { values) }\end{array}$ & $\begin{array}{l}56.25 \mathrm{aA} \\
( \pm 15.63)\end{array}$ & $\begin{array}{l}44.63 \mathrm{aA} \\
( \pm 5.34)\end{array}$ & $\begin{array}{l}54.75 \mathrm{aA} \\
( \pm 14.07)\end{array}$ & $\begin{array}{l}48,73 \mathrm{aA} \\
( \pm 5.09)\end{array}$ & $\begin{array}{l}31.77 \mathrm{bA} \\
( \pm 8.44)\end{array}$ & $\begin{array}{c}47.04 \mathrm{aA} \\
( \pm 6.71)\end{array}$ \\
\hline Oxidative burst & $(\%)$ & $\begin{array}{c}29.45 \mathrm{aA} \\
( \pm 2.63)\end{array}$ & $\begin{array}{l}26.40 \mathrm{aA} \\
( \pm 2.29)\end{array}$ & $\begin{array}{l}19.75 \mathrm{bB} \\
( \pm 1.87)\end{array}$ & $\begin{array}{l}25.24 \mathrm{aA} \\
( \pm 2.58)\end{array}$ & $\begin{array}{l}33.67 \mathrm{aA} \\
( \pm 3.86)\end{array}$ & $\begin{array}{l}25.18 \mathrm{aA} \\
( \pm 3.43)\end{array}$ \\
\hline & $\begin{array}{l}\text { GMFI } \\
\text { (arbitrary } \\
\text { values) }\end{array}$ & $\begin{array}{l}222.34 \mathrm{aA} \\
( \pm 39.52)\end{array}$ & $\begin{array}{c}272.25 \mathrm{aA} \\
( \pm 54.03)\end{array}$ & $\begin{array}{l}135.25 \mathrm{bA} \\
( \pm 37.68)\end{array}$ & $\begin{array}{l}289.02 \mathrm{aA} \\
( \pm 60.62)\end{array}$ & $\begin{array}{l}117.73 b B \\
( \pm 18.17)\end{array}$ & $\begin{array}{c}247.51 \mathrm{aA} \\
\pm 10.55)\end{array}$ \\
\hline
\end{tabular}

Uppercase letters (A,B) indicate significant differences between groups, and lowercase letters $(\mathrm{a}, \mathrm{b})$ indicate significant differences between the time for each group. $(P \leq 0.05)$ 


\section{DISCUSSION}

In most studies, surgical castration caused a rapid increase in serum cortisol concentration, noted at 0.5 to 6 hours from the procedure, which was elevated because no analgesic protocol was administered. This remained high for at least 12 hours after castration and returned to basal levels within 24 hours of the procedure (Stafford et al, 2002; Mellor et al, 2002; Ting et al, 2003; Ballou et al, 2013; Webster et al., 2013). In our research, we did not focus on measuring acute stress; therefore, the serum cortisol concentration was measured after longer intervals, but over more time, something that was not considered by other researchers, who limited their analyses to 3 days after the castration (Stafford et al, 2002; Ballou et al, 2013; Webster et al., 2013). Studying weight gain, Ting et al. (2003) and Hulbert et al. (2011) speculated the castration could generate a chronic stress, which could be observed after 5 days. Their results may be comparable with our previous results (Bellinazzi et al, 2013), and with the results of this current study, high serum cortisol on Day 7 had been observed.

Chronic stress and pain are difficult to prove, and a decrease in daily weight gain is considered as poor indicator (Molony et al., 1995, Becker et al, 2012). Better indicators seem to be behavioral changes that accompany inflammatory processes or cortisol measures (Molony et al., 1995), such as seen with prolonged rubber ring castration of calves (Thuer et al, 2007).

In the study reported here, none of the animals experienced inflammatory processes such as, wound infection, edema; neither systemic illness, or postsurgical hemorrhage which are commonly observed in calves after orchiectomy (Stafford et a, 2002; Pang et al, 2009; Coetzee et al, 2010). Thus, the unique stress indicator observed in these bulls was the serum cortisol concentration increase in the castrated group compared to the sham group.

This serum cortisol concentration increase was smaller than those observed in most other similar studies (Mellor et al, 2002; Stafford et al, 2002; Thuer et al, 2007; Becker et al, 2012; Ballou et al, 2013; Webster et al, 2013). Probably because in stress study models, both human and bovine temperaments have influenced serum cortisol concentrations (Kunz-Ebrecht et al, 2003; Thuer et al., 2007), and the bulls were not acclimated for as long as the bulls in this study.

For the bronchoalveolar analyses, we found an alveolar macrophages functions (phagocytosis and oxidative burst) decrease after the orchiectomy in the castrated group. These facts occur at the same time that the serum cortisol concentration increased for the castrated group compared to the sham group. Similarly, the immune function is affected by other stressful practices, also resulting in an impaired defense (Ishizaki et al, 2005; Bertagnon et al, 2011) however, we believe that the influence of stressful procedures on the alveolar macrophage function of the respiratory tract was studied for the first time in our study of a bovine orchiectomy model.

We also found an alveolar macrophage decrease on D1 for the castrated group. This fact and the alveolar macrophage function decrease could feature an immunocompromised. It could cause a compensatory neutrophilic chemotaxis to maintain a healthy respiratory tract (Flagliary 2003; Ackermann, 2010). Neutrophil influx probably occurred in the respiratory tract one day after the orchiectomy, as in our previous study for some of the castrated animals ( 3 in a total of 8) (Bellinazzi et al, 2013). In our previous study, we didn't find statistical difference for the alveolar macrophage percentage after orchiectomy, probably because BAL cytology was analyzed by optical microscopy. This technique is less sensitive to identify cell populations compared to the technique of flow cytometry, because it evaluated few cells (Steiler et al, 2012) and didn't use specific cell markers, such as alveolar macrophage auto fluorescence (Soethout et al.,2004).

There were no significant differences in alveolar macrophage and their functions for the sham animals, so we can discard the hypothesis that the collection procedure, the stress of handling, the hygiene of the premises or the use of drugs promoted the changes found here, which contradicts the hypothesis of Taylor et al. (2010) who correlated the increase in respiratory disorders after castration are more correlated to management practices such as hygiene, rather than to the procedure itself. 
At D 7, the serum cortisol concentration remained increased and the percentage of phagocytosis and the GMFI of the oxidative burst by the alveolar macrophages remained reduced but the alveolar macrophage returned to basal values. Therefore, this response suggests that orchiectomy is a risk factor for BRD (Ackerman et al, 2010 ) for a period higher than that reported in the literature, that limited their analyses to 3 days after the castration (Stafford et al, 2002; Ballou et al, 2013; Webster et al., 2013).While this study model proves that orchiectomy causes bronchoalveolar cell immune impairment, whether the procedure increases the BRD morbidity is unknown because only cellular function was observed.

\section{CONCLUSION}

Surgical castration suppresses bronchoalveolar functions, with a progressive worsening of the effectiveness of the lung cellular defense for a minimal period of 7 days. The results of the present study indicate that following orchiectomy, respiratory defenses are temporarily depressed, which affects the restoration of the dynamic immune responses needed to prevent disease.

\section{ACKNOWLEDGEMENTS}

Financial support FAPESP- 2011/ 21606-3

\section{REFERENCES}

ACKERMANN, M.R.; DERSCHEID, R.; ROTH, J.A. Innate immunology of bovine respiratory disease. Vet. Clin. N. Am. Food. Anim. Pract., v.26, p.215-228, 2010.

ANDERSON, N. Castration of calves. Facts Anim. Sci., v.29, p.20-42, 2004.

BALLOU, M.A.; SUTHERLAND, M.A.; BROOKS, T.A. et al. Administration of anesthetic and analgesic prevents the suppression of many leukocyte responses following surgical castration and physical dehorning. Vet. Immunol. Immunopathol., v.151, p.285-293, 2013.

BATISTA，C.F.; BLAGITZ，M.G.; SANTOS, B.P. et al. Maturation of mononuclear phagocytes in the lungs of young calves - In vitro study. J. Dairy Sci., v.95, p.5909-5915, 2012.
BECKER, J.; DOHERR, M.G.; BRUCKMAIER, R.M. et al. Acute and chronic pain calves after different methods of rubber-ring castration. Vet. $J$. v.194, p.380-385, 2012.

BELLINAZZI, J.B.; BERTAGNON, H.G.; BATISTA, C.F. et al. Efeitos do estresse da orquiectomia na citologia broncoalveolar de bezerros da raça Holandesa. Pesqui. Vet. Bras., v.33, p.93-98, 2013.

BERTAGNON, H.G.; ESPER, G.V.Z.; EMANUELLI, M.P. et al. Influência meteorológica no leucograma e na população citológica do trato respiratório de bezerros. Pesqui. Vet. Bras., v.31, p.244-246, 2011.

COETZEE, J.F.; GEHRING, R.; TARUSSANG, J. et al. Effect of sub-anesthetic xylazine andketamine ('ketamine stun') administered to calves immediately prior to castration. Vet. Anaesth. Analg., v.37, p.566-578, 2010.

FAGLIARI, J.J. Estudo clínico e laboratorial da pneumonia de bezerros induzida pela inoculação intrabronquial de Mannheimia haemolytica. Arq. Bras. Med. Vet. Zootec., v.55, p.8-14, 2003.

HULBERT, L.E.; CARROLL, J.A.; BURDICK, N.C. et al. Innate immune responses of temperamental and calm cattle after transportation. Vet. Immunol. Immunopathol., v.143, p.66-74, 2011.

ISHIZAKI, H.; HANAFUSA, Y.; KARIYA, Y. Influence of truck transportation on the function of bronchoalveolar lavage fluid cells in cattle. Vet. Immunol. Immunopathol., v.105, p.67-74, 2005.

KUNZ-EBRECHT, S.R.; MOHAMED-ALI, A.; FELDMAN, P.J. et al. Cortisol responses to mild psychological stress are inversely associated with proinflammatory cytokines. Brain Behav. Immun., v.17, p.373-383, 2003.

MAC VEAN, D.W.; FRANZEN, D.K.; KEEFE, T.J. et al. Airbone particle concentration and meteorologic conditions associated with pneumonia incidence in feedlot cattle. Am. J. Vet. Res., v.47, p.2676-2682, 1986.

MELLOR, D.J.; STAFFORD, K.J.; TODD, S.E. et al. A comparison of catecholamine and cortisol responses of young lambs and calves to painful husbandry procedures. Aust. Vet. J., v.80, p.228-233, 2002. 
MOLONY, V.; KENT, J.E.; ROBERTSON, I.S. Assessment of acute and chronic pain after different methods of castration of calves. Appl. Anim. Behav. Sci., v.46, p.33-48, 1995.

PANG, W.Y.; EARLEY, B.; SWEENEY, T. et al. Effects of banding or burdizzo castration of bulls on neutrophil phagocytosis and respiratory burst, CD 62-L expression, and serum interleukin-8 concentration. J. Anim. Sci., v.87, p.3187-3195, 2009.

PINCHAK, W.E.; TOLLESON, D.R.; MCCLOY, M. Morbidity effects on productivity and profitability of stocker cattle grazing in the Southern Plains. J. Anim. Sci., v.82, p.27732779, 2004.

SNOWDER, G.D.; VAN VLECK, L.D.; CUNDIFF, L.V. et al. Bovine respiratory disease in feedlot cattle: environmental, genetic, and economic factors. J. Anim. Sci., v.84, p.19992008, 2006.

SOETHOUT, E.C.; MÜLLER, K.E.; VAN DEN BELT, A.J.M. et al. Identification and phenotyping of leukocytes in bovine bronchoalveolar lavage fluid. Clin. Diagn. Lab. Immunol., v.11, p.795-798, 2004.

STAFFORD, K.J.; MELLOR, D.J.; TODD, S.E. et al. Effects of local anaesthesia or local anaesthesia plus a non-steroidal antiinflammatory drug on the acute cortisol response of calves to five different methods of castration. Res. Vet. Sci., v.73, p.61-70, 2002.
STEILER, J.; BERNARDO, B.S.; DONOVAN, G.N. Neutrophil and monocyte function in neonatal dairy calves fed fresh or frozen colostrum. Intern. J. Appl. Res. Vet. Med., v.10, p.328-334, 2012.

TAYLOR J.D.; FULTON, R.W.; LEHENBAUER, T.W. et al. The epidemiology of bovine respiratory disease: what is the evidence for predisposing factors. Can. Vet. J., v.51, p.1095-1102, 2010.

THUER, S.; MELLEMA, S.; DOHERR, M.G. et al. Effect of local anaesthesia on short- and longterm pain induced by two bloodless castration methods in calves. Vet. J., v.173, p.333-342, 2007.

TING, S.T.L.; EARLEY, B.; HUGHES, J.M.L. et al. Effect of ketoprofen, lidocaine local anesthesia, and combined xylazine and lidocaine caudal epidural anesthesia during

castration of beef cattle on stress responses, immunity, growth, and behavior. J. Anim. Sci., v.81, p.1281-1293, 2003.

WEBSTER, H.B.; MORIN, D.; JARRELL, V. et al. Effects of local anesthesia and flunixin meglumine on the acute cortisol response, behavior, and performance of young dairy calves undergoing surgical castration. J. Dairy. Sci., v.96, p.6285-6300, 2013. 